\title{
Understanding Carer Resilience in Duchenne Muscular Dystrophy: A Systematic Narrative Review
}

Glover, S., Hendron, J., Taylor, B., \& Long, M. (2020). Understanding Carer Resilience in Duchenne Muscular Dystrophy: A Systematic Narrative Review. Chronic IIIness, 16(2), 87-103. https://doi.org/10.1177/1742395318789472

Link to publication record in Ulster University Research Portal

\section{Published in:}

Chronic Illness

Publication Status:

Published (in print/issue): 01/06/2020

DOI:

$10.1177 / 1742395318789472$

\section{Document Version}

Author Accepted version

\section{General rights}

Copyright for the publications made accessible via Ulster University's Research Portal is retained by the author(s) and / or other copyright owners and it is a condition of accessing these publications that users recognise and abide by the legal requirements associated with these rights.

\section{Take down policy}

The Research Portal is Ulster University's institutional repository that provides access to Ulster's research outputs. Every effort has been made to ensure that content in the Research Portal does not infringe any person's rights, or applicable UK laws. If you discover content in the Research Portal that you believe breaches copyright or violates any law, please contact pure-support@ulster.ac.uk. 
Glover AS, Long M, Hendron J \& Taylor BJ (in press) Understanding carer resilience in Duchenne Muscular Dystrophy: a systematic narrative review.Chronic Illness [advance access; accepted 11 June 2018]

\section{Understanding Carer Resilience in \\ Duchenne Muscular Dystrophy: A \\ Systematic Narrative Review}


Glover AS, Long M, Hendron J \& Taylor BJ (in press) Understanding carer resilience in Duchenne Muscular Dystrophy: a systematic narrative review.Chronic Illness [advance access; accepted 11 June 2018]

\section{Abstract}

\section{Objectives:}

This review synthesizes recent research on resilience in those who care for a family member with Duchenne Muscular Dystrophy (DMD), identifying the challenges and potential factors moderating resilience.

\section{Methods:}

This systematic narrative review is informed by searches on six bibliographic databases between January and June 2016. Forty-one articles were identified to meet the inclusion criteria, and findings were synthesised around three key themes.

\section{Results:}

Those who care for someone with DMD have been described as resilient through building strength in facing the adversity of caring. The main predictors of carer resilience were the child's level of disability, perception of the caring experience and family functioning. The outcomes of resilience were identified as better psychological and physical health as well as psychological adaption. Coping abilities and social support, influenced by individual and environmental factors contribute to resilience.

\section{Discussion:}

Research suggested that some carers have the ability to build resilience over time, although limited understanding of coping with the emotional experience of DMD is conveyed. Social support appears to be a protective factor for DMD carers but further research is required on its relationship with resilience.

Keywords: Duchenne Muscular Dystrophy, Resilience, Systematic Narrative Review, Social Support, Parents. 
Glover AS, Long M, Hendron J \& Taylor BJ (in press) Understanding carer resilience in Duchenne Muscular Dystrophy: a systematic narrative review. Chronic IIIness [advance access; accepted 11 June 2018]

\section{Introduction}

Duchenne Muscular Dystrophy (DMD) is a genetic condition affecting 1 in 5136 live male births in the UK. (1) There is no cure for DMD and in comparison to other childhood forms of muscular dystrophy DMD is the most severe. ${ }^{(2)}$ The condition causes progressive muscle weakness leading to a loss of ambulation in childhood and limited upper limb use in its later stages. ${ }^{(3)}$ As well as physical limitations, those with DMD are at a higher risk of intellectual impairments such as autism. ${ }^{(4)}$ The development of glucocorticoid therapy, cardiac management and non-invasive ventilation has increased life expectancy into the third and fourth decade of life. ${ }^{(5)}$ Children and young adults with DMD require assistance with all aspects of daily living as the condition progresses. Ordinarily, this responsibility is assumed by parents and close family members. ${ }^{(6)}$

It is crucial for research on the caring experience to acknowledge the clinical features of the condition.

(7) Undoubtedly, devoting a life to caring is challenging. It has been suggested that caring for a person with DMD is a unique experience involving constant care changes to meet increasing demands coupled with awareness of a shortened life. ${ }^{(8)}$ However, research has also focused on the personal strengths and often positive outcomes of caring for a family member with DMD. ${ }^{(7)}$ Understanding the mechanisms that contribute to resilience in the face of demands would be protective for the carer and care receiver. This is especially important given the role of the family carer in providing essential support for those with complex needs. ${ }^{(9)}$ Yet, resilience in the context of caring has received limited attention. $^{(10)}$

Despite the term "resilience" growing in use in research on patients and families, there is no universal definition. ${ }^{(11)}$ The term describes the phenomena understanding the processes involved in positive outcomes despite facing threatening, adverse circumstances ${ }^{(12)}$ The Resilience Framework by Kumpfer ${ }^{(13)}$ suggests that resilience is a process involving the individual, their environment and internal resilience competencies resulting in a positive outcome following adversity. Internal self- 
Glover AS, Long M, Hendron J \& Taylor BJ (in press) Understanding carer resilience in Duchenne Muscular Dystrophy: a systematic narrative review. Chronic IIIness [advance access; accepted 11 June 2018]

resiliency competencies can be demonstrated through a successful stress-coping ability. ${ }^{(14)}$ Examining how individuals cope with the emotional experience of facing adversity can enhance the understanding of resilience. ${ }^{(15)}$ Resilience can also be examined by understanding its relationship with factors believed to contribute to its presence, such as perceived social support..$^{(16)}$

The growing interest and lack of consensus about the concept has resulted in a fragmented idea of how resilience should be measured. Resilience has been defined as a personality characteristic ${ }^{(17)}$ or the closely related term 'hardiness' which suggests durability but not necessarily a positive outcome. ${ }^{(18)}$ Others have described resilience as a developed ability to cope with stressors. ${ }^{(14)}$ Qualitative research suggests that resilience can be understood as the family's attempt to generate positive meaning of the caring experience. ${ }^{(19)}$ For the purpose of this review the research question was defined as "What is the current understanding of resilience in those who care for someone with DMD?".

\section{Methodology of the Systematic Narrative Review}

Systematic reviews need not be limited to questions of effectiveness, ${ }^{(20,21)}$ but can encompass questions of prevalence and correlation (as measured by surveys) and questions of lived experience and creating theoretical understandings (as explored by qualitative studies). Unlike the traditional Systematic Review, adopting a narrative approach enables the integration of qualitative and quantitative studies to review a phenomenon ${ }^{(20)}$. To be rigorous, the review must be logical and have a clearly defined approach to identifying and synthesising the previous research. ${ }^{(22)}$ The methodology of this study was guided by PRISMA (Preferred Reporting Items for Systematic reviews and MetaAnalysis). ${ }^{(23)}$ 
Glover AS, Long M, Hendron J \& Taylor BJ (in press) Understanding carer resilience in Duchenne Muscular Dystrophy: a systematic narrative review. Chronic IIIness [advance access; accepted 11 June 2018]

\section{Search Strategy}

A search strategy was developed with specialist librarian assistance (see appendix 1). Following an initial scoping of the literature, search terms were formulated across three concept groups relating to (1) the condition, (2) the carer and (3) resilience factors. The aim of the search strategy was to reduce the number of irrelevant articles before a further inclusion and exclusion criteria was applied to results.

\section{Selection of Studies}

Searches were initially run in January 2016 and updated in June 2016 across 6 databases including Applied Social Sciences Index and Abstracts (ASSIA), Cumulative Index to Nursing and Allied Health (CINAHL Plus), Medline, PsycInfo, Scopus and Social Citation Index. The initial search in January 2016 retrieved 170 studies and an updated search in June 2016 received 6 studies (see figure 1). Following the database searches, further selection was carried out as explained below.

To be included in the review studies had to be empirical and focus on the family carer of a child or adult with DMD. Initial searches yielded no studies specifically measuring resilience in this group, so the search was widened to include the potential assets and resources relating to DMD.

The inclusion and exclusion tool was developed as a guide for decision making regarding articles from within the 176 retrieved studies to be included in the review (see table 1). ${ }^{(24)}$ An initial screening removed 5 retrieved studies that were written in a language other than English. Articles published prior to 1990 were excluded. The rationale for this exclusion was based on evidence of development in the management of DMD with steroids and ventilation ${ }^{(24)}$. In turn, this may have altered carers' perceptions on the progression of the condition.

Table 1: Inclusion and Exclusion Criteria (end of document) 
Glover AS, Long M, Hendron J \& Taylor BJ (in press) Understanding carer resilience in Duchenne Muscular Dystrophy: a systematic narrative review. Chronic IIIness [advance access; accepted 11 June 2018]

Using the researcher-developed inclusion and exclusion tool, the retrieved studies were inspected independently by two of the research team, and 26 studies were identified as meeting the inclusion criteria. Database searching provides a relatively unbiased approach for the first stage of study identification, but is not a complete approach on its own. ${ }^{(21,26)}$ An additional 16 studies were retrieved by examining the reference list of the selected 26 studies, and running citation searches across each database.

\section{Appraisal of Quality}

Quality appraisal methods traditionally used for experimental studies of effectiveness would not be suitable given the diverse study designs included in this research. Published quality appraisal tools for qualitative (QAT-Q), and survey (QAT-S) methods can be used to summarise and appraise studies (authors own). The QAT-Q and QAT-S are suitable for the appraisal of studies which focus on a defined population, thus proving suitable for this review. The first author used the QAT-Q and QAT-S tool to summarise the purpose of the study, methodology, key findings as well as comment on the quality and relevancy of the study to the research question. Grey literature was excluded and all studies in the review were published in peer reviewed journals.

\section{Synthesis}

Research synthesising quantitative and qualitative data can adopt integrative and interpretative approaches. An integrative review aims to amalgamate data with techniques such as meta-analysis. In contrast, an interpretive review involves both induction and interpretation using methods such as narrative summary. Choosing an approach can be influenced by the evidence being synthesised. (20) This review will adopt an interpretive approach given the range of study designs addressing the research question. Similarly, to a narrative summary, a thematic analysis provides a compressive approach to bringing together reoccurring themes answering the research question. ${ }^{(20,27)}$ Using the summaries of the 41 studies, key findings were extracted that gave an understanding of resilience in 
Glover AS, Long M, Hendron J \& Taylor BJ (in press) Understanding carer resilience in Duchenne Muscular Dystrophy: a systematic narrative review. Chronic IIIness [advance access; accepted 11 June 2018]

those caring for someone with DMD. This thematic analysis of summaries was conducted by the first author followed by a synthesis of data that was achieved through tabulation. The consensus of the research team reduced a total of 12 themes into the three main themes (see appendix 2). Included studies that answered the research question with greatest detail were used as a foundation to explore themes.

\section{Overview of Results}

A total of 41 articles were included in this synthesis. Six studies were published between 1990-2001 and 14 were published between 2008 and 2013 (n=14). 11 studies were published between 2014 and 2016. 30 studies reported on survey methods and 10 reported on semistructured interviews. One case study was also included. Forty studies were conducted with family carers and one study examined perceptions of health-care professionals. None of the surveys retrieved included the data collection tool within the paper. Two ${ }^{(27,39)}$ of the studies used only researcher developed data collection tools while the remaining studies used researcher developed and validated tools. A descriptive summary of topics measured is listed below:

- health of the person being cared for $(30,31,32,34,36,41,44,47,52,54,63,64,66,69)$

- $\quad$ carer burden $(6,30,37,45,54-56,64,66)$

- $\quad$ carer well-being $(6,7,31,32,34,37,41,44,45,47,50,52-55,57,58,57,66,69)$

- family resilience $(41,45,47)$

- Family hardiness $(47,50,52)$

- $\quad$ social support $(7,41,44,47,50,52,56,69)$ 
Glover AS, Long M, Hendron J \& Taylor BJ (in press) Understanding carer resilience in Duchenne Muscular Dystrophy: a systematic narrative review.Chronic Illness [advance access; accepted 11 June 2018]

Nine of the 41 studies were carried out in the USA, eight in Canada, five in the United Kingdom. The remaining studies were carried in Taiwan, Italy, Japan, Brazil, France, Australia, Netherlands, India, and Turkey. (see appendix 2).

Thirteen studies described the past, present and future challenges faced by carers in the family unit. Three of the included studies conceptualised carers as resilient while six studies sought to measure resilience or the closely-related concept of 'hardiness'. Nineteen studies considered possible static and dynamic factors as well as the support mechanisms potentially moderating resilience in carers of people with DMD. The synthesis below is structured according to the three themes stated earlier in this paper:

1. Past, present and future challenges

2. Measurement, predictors and outcomes of resilience

3. Internal and external factors that moderate resilience in carers

\section{Results}

\section{Past Present and future challenges}

This section discusses the life events, stressors and psychological issues faced by carers structured around the past, present and future challenges identified in the literature.

Past

A mixed methods study by Green and Murton ${ }^{(28)}$ reported that shock was the most reported reaction to the diagnosis, seemingly understandable as the majority of participants reported they had little to no understanding of the condition. Furthermore, the challenge of diagnosis goes beyond the reactions of the carer to the task of explaining the nature of the condition to the affected child. ${ }^{(29)}$ 
Glover AS, Long M, Hendron J \& Taylor BJ (in press) Understanding carer resilience in Duchenne Muscular Dystrophy: a systematic narrative review. Chronic IIIness [advance access; accepted 11 June 2018]

Present

Landfeldt et al. ${ }^{(30)}$ found that almost half of the carers in the study experienced feeling moderately to extremely anxious or depressed. This was associated with the carers' perception of the health status of the person they cared for. The objective ambulatory status did not influence feelings of anxiety or depression. Mah et al. ${ }^{(31)}$ compared health-related quality of life and stress among 109 parents caring for a child with or without home ventilation. The study found that carer stress was not greater in parents caring for a child on home ventilation or parents caring for an unaffected child. Although the finding is perhaps a result of the perception of normality of caring duties among carers, consideration should be given to selection bias. Mah et al ${ }^{(31)}$ highlights that less than half of eligible sample took part in the research suggesting that those with greater levels of stress may not have participated. Further studies suggest that stress stems from challenges beyond the provision of physical care needs, including behavioural issues and psychological adjustment of the person being cared for. ${ }^{(32,33)}$ Yilmaz et al. ${ }^{(34)}$ reported that time devoted to caring increased social isolation, while Mah et al. ${ }^{(35)}$ proposed that isolation could be self-imposed based on worry of the perception of the community and the child's exposure to contractible illness. Additionally, challenges went beyond the psychological domain as carers reported problems with their quality of sleep. ${ }^{(36)}$

\section{Future}

Experiencing a fear of the future was the most commonly reported psychological issue among the majority of carers of people with DMD. ${ }^{(37)}$ Peay et al. ${ }^{(38)}$ aimed to assess parent's prioritization of worries related to DMD as a means of understanding the impact of the condition. According to the authors, this study is the first to use Best-Worst Scaling to prioritise emotion-focused illness depictions. Participants were asked to rate worries across four domains, those relating to the child, medical worries, parental wellbeing and family life. In the parental wellbeing domain, parents worried most about managing their uncertainty about the child's future. Given the progressive nature of the condition, fears arise around the responsibilities of caregiving when children become young men. ${ }^{(39)}$ 
Glover AS, Long M, Hendron J \& Taylor BJ (in press) Understanding carer resilience in Duchenne Muscular Dystrophy: a systematic narrative review. Chronic IIIness [advance access; accepted 11 June 2018]

However, evidence suggests that parents are aware of their future emotional needs and rank mental health services as important when facing the latter years of the condition. ${ }^{(40)}$

\section{Measurement, predictors and outcomes of resilience}

Despite the challenges faced by carers, the findings demonstrated resilience among carers. ${ }^{(41)}$ Three studies used the term resilient when describing carers of people with DMD and 6 studies sought to quantitatively measure the predictors and outcomes of resilience.

Conceptualising carers of people with DMD as resilient

A phenomenological study by Gravelle ${ }^{(42)}$ aimed to explore carers' day to day experiences. The caring experience was conceptualised as facing adversity where carers continually redefined their adversity as the condition progressed. One theme identified as part of the process of defining adversity included the strength gained through their hardship. Gravelle ${ }^{(42)}$ used the term resilient to describe this personal strength building. Carers have also been described as demonstrating resiliency through their development of coping strategies ${ }^{(43)}$ and adjustment to the condition ${ }^{(44)}$

Predictors of resilience

A study by Peay et al. ${ }^{(45)}$ investigated resilience contributing to an outcome of psychological adaption as well as examining the factors contributing to carer resilience. The study conceptualised resilience as protective factors from the individual and social resources measured using the Resilience Scale for Adults (RSA). ${ }^{(46)}$ The results suggested that resilience better predicted psychological adaption in a two year follow up than perceived burden and functional independence of the child. However, resilience was challenged when there was more dependency on carers. In Chen and Clark's ${ }^{(47)}$ work, the Resiliency Model of Family Stress, Adjustment and Adaption ${ }^{(48)}$ was used as a framework to investigate family functioning. Family functioning is the use of family resources to cope with the condition and build family resilience. In contrast to Peay et al., ${ }^{(45)}$ Chen and Clark ${ }^{(47)}$ found that the child's level of disability did not affect the family functioning. The authors reported that stressors could be a result 
Glover AS, Long M, Hendron J \& Taylor BJ (in press) Understanding carer resilience in Duchenne Muscular Dystrophy: a systematic narrative review.Chronic Illness [advance access; accepted 11 June 2018]

of the anxiety and emotional response to the condition, suggesting that families have adopted their own means of coping with daily care.

The care experience itself has been attributed to resilience. ${ }^{(7)}$ Magliano et al. ${ }^{(7)}$ found that $18 \%$ carers made reference to the caring experience being positive and contributing to their resilience. Analysed within the Transactional Model of Stress, ${ }^{(49)}$ the research suggested that when carers feel they have the resources to meet the demands of caring, they can recognise the positive aspects of their role. These resources could be influenced by the timing of the diagnosis since earlier recognition of DMD provides a longer period of time to learn about the condition and manage its progression. ${ }^{(50)}$ Also conceptualised in the Resiliency Model of Family Stress, Adjustment and Adaption, ${ }^{(48)}$ Chen $^{(50)}$ suggested that an earlier diagnosis increases the family functioning when there was a presence of hardiness, measured as an energy source used in the face of adversity. According to the authors, family functioning represents the family's abilities to communicate, problem solve and exert behavioural control. Parents who perceive their family as hardy may be more able to manage the stress of caring for a child with DMD and maintain a level of family functioning. The authors suggest this may be because parents who received a diagnosis earlier had greater amount of time to seek support and build hardiness supporting family functioning, prior to a deterioration in their child's health.

\section{The outcome of resilience}

Kenneson and $\mathrm{Bobo}^{(41)}$ measured resilience as an ability to achieve positive adaption when enduring stress using the Brief Resilient Coping Scale. ${ }^{(51)}$ A total of $89.3 \%$ carers reported high levels of selfperceived resilience. This resilience played a positive role in all three of the outcome variables examined. Outcome come variables included life satisfaction, stress and distress. Function and quality of social support was also measured and lower levels predicted a negative role in the outcome variables. However, the research did not examine interactions between resilience and social support. ${ }^{(41)}$ It also remains unclear if lower levels of resilience and social support are a cause or a result of stress, highlighting the need to examine the process of resilience. 
Glover AS, Long M, Hendron J \& Taylor BJ (in press) Understanding carer resilience in Duchenne Muscular Dystrophy: a systematic narrative review. Chronic IIIness [advance access; accepted 11 June 2018]

Furthermore, understanding of resilience has relevance for the physical domains of health. Chen and Clark ${ }^{(52)}$ extended their previous research on the Resiliency Model of Family Stress, Adjustment and Adaption $^{(48)}$ and assessed the contributing factors to perceived parental health. In the presence of greater hardiness and family support, parents had a more positive perception of their own health. Perception of health was not negatively associated with objective measures of the child's disability but with more subjective measures. This is identified as an area for further investigation.

\section{Internal and external factors that moderate resilience in carers. '}

The scope of this study was widened to include articles describing potential factors that could moderate resilience in those who care for someone with DMD. This included 24 articles relating to coping abilities and supportive mechanisms.

\section{Coping Abilities}

Several studies included the emotional experience of caring for someone with DMD, with coping identified to be of paramount importance in facilitating emotional adaptation ${ }^{(6,44,53-62)}$. James et al. ${ }^{(53)}$ discussed the emotionality of the caring experience and warned that mothers can experience guilt relating to the genetic inheritance of the condition. When guilt is not managed by effective coping, both parents express blame consequently affecting family functioning. ${ }^{(53)}$

A study by Pangalila et al. ${ }^{(6)}$ examined subjective burden when caring for an adult son with DMD. The quantitative study suggested that carers experience a great deal of burden but continue to perceive the caring experience to be positive. While some studies suggested that burden is increased with the time spent caring ${ }^{(54)}$ others argued that perceived burden is influenced by the emotions experienced when caring, even when the child is in the early stages of the condition. ${ }^{(55,56)}$

Abi-Doud ${ }^{(57)}$ aimed to examine depression, self-esteem and mastery of family carers in comparison with a normative population. The study found that those caring for someone with DMD could have fewer emotional coping skills in particular and were significantly more likely to suffer from a major 
Glover AS, Long M, Hendron J \& Taylor BJ (in press) Understanding carer resilience in Duchenne Muscular Dystrophy: a systematic narrative review. Chronic IIIness [advance access; accepted 11 June 2018]

depressive disorder than the normative population. This deficit in emotional coping skills was attributed to lower self-esteem and mastery scores. Thompson et al. ${ }^{(44)}$ found that the self-reported poor adjustment of $57 \%$ of participants was related to greater use of emotion focused coping, particularly around the use of avoidance, wishful thinking and self-blame. Similarly, Chen et al. ${ }^{(58)}$ compared parents with a child in hospital with a fever and DMD. Those caring for a child with DMD were less likely to use coping skills except for a greater use of wishful thinking. Avoidance was further explained by Gagilardi ${ }^{(59)}$ who suggested that parents became afraid of the over-whelming rush of sorrow, fear and anger when discussing the condition and in response avoided confrontation. Similarly, in the context of the marital relationships, carers expressed a preference for avoiding discussion of DMD resulting in greater family stress. ${ }^{(60)}$

Despite the difficulties in coping, the evidence suggested that emotions are facilitative for those caring for someone with DMD. ${ }^{(61,62)}$ Erby et al. ${ }^{(61)}$ examined carers perceptions of care planning for later stages in their sons' lives. They suggested that parents moved between feelings of avoidance, hope and presence, each playing an adaptive role in the trajectory of the condition. In particular, a sense of presence, where parents took each day as it came and upheld living life to the full, enabled them to be most receptive to discussions around planning for the future. Hope in the process of adapting to DMD has also been examined by Samson et al. ${ }^{(62)}$ Analyzing 12 interviews using a phenomenological approach, the authors reported that hope emerges through the cognitive appraisal of the condition, a key element of adaption. In line with the cognitive appraisal, hope changes and acts as a resource enabling parents to develop and meet the demands of caring.

Developing the skills to cope

The literature suggested that coping is a resource that can be developed despite the apparent problems around coping abilities. Bray ${ }^{(63)}$ reported that the greatest emotional impact was experienced during the early stages of the condition. Boyer ${ }^{(55)}$ related that older carers experience less burden, which was attributed to exposure to challenging situations resulting in developing greater 
Glover AS, Long M, Hendron J \& Taylor BJ (in press) Understanding carer resilience in Duchenne Muscular Dystrophy: a systematic narrative review. Chronic IIIness [advance access; accepted 11 June 2018]

tolerance to burden and evolving problem-solving strategies. Thus suggesting that the emotional impact during the early stages of the condition could lead to the development of carer coping skills.

\section{Strength of the family unit}

Tomiak et al. ${ }^{(8)}$ examined the lived experiences of the process of adjustment to DMD when facing loss, experiencing and expressing emotions and changes in family life. Although mothers and fathers coped with the condition differently, partners who had the ability to work together and provide support felt that their relationship was strengthened. Family cohesion was found to strengthen as the child's psychological health progresses in response to coping with the child's psychological difficulties. ${ }^{(64)}$

Read et al. ${ }^{(65)}$ examined the impact of DMD on siblings and suggested that family cohesion was a protective aspect during the adaption process. They found that siblings perceived cohesion to be greater when families had engaged in problem solving and communicated difficult emotional topics. This finding supported earlier quantitative studies where siblings experienced greater emotional difficulties when family communication was lacking. ${ }^{(66)}$

The role of support mechanisms

Examining the wider literature facilitates greater insight into; the role of social support as a potential buffering factor adversity, as well as understanding the issues impeding social support. Magliano et al. ${ }^{(56)}$ aimed to explore burden and the role of social and professional support in families. Through the sharing of experiences, Magliano et al. ${ }^{(56)}$ suggest that social resources could well be a protective factor against burden. Carers felt supported with $82 \%$ reporting they were confident in receiving emergency professional help and $30.2 \%$ recommending psychological support for other families. In the presence of social support carers, are more likely to feel satisfied with life ${ }^{(41)}$ Conversely, a lack of social network including spouse or employment can lead to carers experiencing greater perceived burden,.$^{(56,64)}$ 
Glover AS, Long M, Hendron J \& Taylor BJ (in press) Understanding carer resilience in Duchenne Muscular Dystrophy: a systematic narrative review. Chronic IIIness [advance access; accepted 11 June 2018]

The research suggested that accessing social support is not a straightforward process. A study comparing American and Irish families with DMD by Fitzpatrick and Barry ${ }^{(60)}$ reported that American families were more instrumental in setting up services to cope with the emotional aspects of the condition. These services were deemed to be particularly important as some parents perceived support from health professionals and the wider family to be inadequate. ${ }^{(67)}$

Tomiak et al. ${ }^{(8)}$ suggested that there are differences between mothers and fathers in the need for social support. For mothers, gaining social support is an important tool in coping with her son's condition. This included being able to seek out support and talk to other friends and family members. Often mothers adopt the role of primary carer for their son, and as such often they are isolated from the wider community. By contrast, often fathers sustain employment and therefore have a network of people to fulfil their social needs. Fathers are also less forthcoming to use social support groups as the differences between families attending can be a hindrance to gaining a sense of mutual understanding.

Additionally, the literature suggested there are differences in the receptivity of social support over time. In the early stages of the condition parents might avoid contact with other families to maintain a sense of normality, avoiding confronting the certainty of the advancing condition. ${ }^{(68)}$ As parents accepted their own situation and developed the capacity for coping they were more able to become involved with other parents. Furthermore, role of the support groups adapted with more focus on social interaction and having fun, and less need for practical support. In turn, parents were aware that they may need help in the near future with the bereavement of their son and therefore hope that their support will be reciprocated. However, other studies have suggested that social support decreases over time, which might be attributed to increasing caring demands. ${ }^{(41,69)}$

\section{Discussion}


Glover AS, Long M, Hendron J \& Taylor BJ (in press) Understanding carer resilience in Duchenne Muscular Dystrophy: a systematic narrative review. Chronic IIIness [advance access; accepted 11 June 2018]

This paper has synthesised current understandings of resilience among carers of people with DMD. Findings were extracted from 41 studies by drawing themes from each of the studies. Following a summary of the findings, the synthesis will be explored in light of the caring and resilience literature. It appears that resilience in those who care for someone with DMD is under researched. Only six studies attempted to measure a resilience construct however the broad research question enabled the inclusion of further insight to the process.

The included studies suggest that DMD carries its own unique journey for carers with past, present and future challenges during the course of their caring responsibilities. Thus supporting the notion that research concerning the caring experience should acknowledge the clinical features of the condition. ${ }^{(7)}$

High levels of resilience have been reported and the notion that intervention strategies could be developed is promising. ${ }^{(41)}$ Chen and Clark ${ }^{(47)}$ noted that over time carers develop the skills to cope with the condition and research has also shown that caring experience leads to greater burden tolerance, ${ }^{(55)}$ which is perhaps a demonstration of carers resilience being in line with the meta-theory of resilience. The meta-theory proposes that through disruption in life, some individuals can identify and develop their protective factors leading to enhanced resilience. ${ }^{(70)}$ Understanding how carers of people with DMD identify and develop protective factors is lacking, especially given the mixed findings on the child's level of independence contributing to resilience.

Understanding of how carers are resilient could be explained by individual abilities to cope with the emotional challenges of caring for someone with DMD. The challenges of caring for someone with DMD may reside in the emotional response to the condition. ${ }^{(47)}$ The existing literature suggests that resilience is a stress-coping ability; emotion-regulating skills are entwined in the resilience process. ${ }^{(14,15)}$ This review has highlighted the role of emotion in the adaptive process. The role of emotion is facilitative in planning for the future ${ }^{(61)}$ and adapting to care demands. ${ }^{(62)} \mathrm{A}$ phenomenological study by Jowsey et al. ${ }^{(71)}$ suggested that worry, an unseen cost of caring, can be 
Glover AS, Long M, Hendron J \& Taylor BJ (in press) Understanding carer resilience in Duchenne Muscular Dystrophy: a systematic narrative review. Chronic IIIness [advance access; accepted 11 June 2018]

both a negative and positive experience. Although worry was disruptive it also enabled alertness and preparation for future needs.

Research measuring resilience and social support in those caring for a child with autism suggests that resilience enables individuals to seek social support effectively and maintain positive relationships. ${ }^{(10)}$ However some carers prefer to be self-sufficient and choose not to seek support. ${ }^{(72)}$ Research on those caring for someone with heart failure suggested that carers feel that they do not want to put pressure on others. ${ }^{(73)}$ It is clear that social support is an important area of enquiry as it acts as a buffer to the burdens of caring, ${ }^{(56)}$ and enables adaption ${ }^{(52)}$. There also appears to be contextual and individual factors that could influence this relationship such as the timing of support, ${ }^{(50,68)}$ drive to access support ${ }^{(60)}$ and factors related to communication and emotional support within the family altering the strength of the family unit. ${ }^{(8,65)}$

A deeper understanding of the challenges, carer resilience and support mechanisms could be gained through qualitative inquiry. The six studies that directly attempted to understand carer resilience were surveys grounded in the quantitative paradigm $(7,41,45,47,50,52)$. Resilience research should cross quantitative and qualitative paradigms. Qualitative studies provide a way of discovering construction of positive meaning and novel resources contributing to resilience. ${ }^{(16,19)}$

\section{Limitations and Future Research Directions}

Some degree of bias could exist within this synthesis. A total of 6 databases were selected by the research team along with a specialist librarian. With fewer time constraints, a greater number of databases could have been searched to increase the scope of the review. The retrieved studies included in this synthesis also had their own risk of bias. The majority of surveys used self-report tools. This could indicate potential bias based on social desirability ${ }^{(31)}$. Furthermore, studies may have been at risk of selection bias. Carers who were more able to give their time to take part in research may represent an alternative caring experience to those not participating ${ }^{(35,44)}$. 
Glover AS, Long M, Hendron J \& Taylor BJ (in press) Understanding carer resilience in Duchenne Muscular Dystrophy: a systematic narrative review. Chronic IIIness [advance access; accepted 11 June 2018]

Although some degree of appraisal of quality was applied, future studies could use more robust methods to assess quality across a range of study designs. The majority of studies included in this review were based in the quantitative paradigm. Qualitative studies that seek to understand the experience and conceptualisation of DMD caring from the carer's perspective represents a valuable area for future research. It has been suggested that development of interventions focusing on resilience would be beneficial. The lack of any intervention studies found in this review supports this notion. Widening the scope of the research enabled the uncovering of potential individual factors and support mechanisms contributing to resilience. Future research could contribute to the development of support interventions to assist family carers in their challenging role caring for a person with DMD.

\section{Conclusion}

This systemic narrative review is the first to be based on the retrieval and synthesis of studies relating to resilience among carers of people with DMD. The review has highlighted that there are few studies examining resilience in carers of people with DMD. However, the systematic narrative review has addressed the research question by revealing that those who care for someone with DMD can be considered as resilient. ${ }^{(41)}$ The perception of the caring experience and factors related to the person being cared for may influence resilience. ${ }^{(7,45)}$ It is clear that resilience is a vital asset to carers as it can reduce stress, promote phycological adaption and improve life satisfaction. (41) A greater understanding of the relationships between social resources, individual competencies and resilience would also be important for enhancing resilience in those who care for someone with DMD.

\section{Acknowledgments}

Special thanks to Joanne Knox, Assistant Subject Librarian, Ulster University, for her technical assistance and support in developing the search strategy.

\section{Conflict of Interest}


Glover AS, Long M, Hendron J \& Taylor BJ (in press) Understanding carer resilience in Duchenne Muscular Dystrophy: a systematic narrative review.Chronic IIIness [advance access; accepted 11 June 2018]

The authors declare that there is no conflict of interest.

\section{Funding}

Financial support for this research was gained from The Department of Education and Learning, Northern Ireland.

\section{References}

1. Moat SJ, Bradley DM, Salmon R et al. Newborn bloodspot screening for Duchenne Muscular Dystrophy: 21 years experience in Wales (UK). Eur J Hum Genet 2013; 21: 1049-1053.

2. Klapac-Rodino LR, Mendell, JR and Sahenk. Update on the Treatment of Duchenne Muscular Dystrophy. Curr Neurol Neurosci Rep 2013; 13:332-339.

3. Bushby K, Finkel R, Birnkrant DJ, et al. Diagnosis and management of Duchenne muscular dystrophy, part 1: diagnosis, and pharmacological and psychosocial management. Lancet Neurol 2010; 9: 77-93.

4. Hendriksen JG and Vles JS. Neuropsychiatric disorders in males with duchenne muscular dystrophy: frequency rate of attention-deficit hyperactivity disorder (ADHD), autism spectrum disorder, and obsessive--compulsive disorder. J Child Neurol 2008; 23: 477-481.

5. Landfeldt E, Lindgreen P, Bell CF et al. Compliance to Care Guidelines for Duchenne Muscular Dystrophy. J Neuromuscul Dis 2015; 2: 63-72.

6. Pangalila RF, van den Bos, Geertrudis AM, et al. Subjective caregiver burden of parents of adults with Duchenne muscular dystrophy. Disabil Rehabil 2012; 34: 988-996.

7. Magliano L, Patalano M, Sagliocchi A, et al. "I have got something positive out of this situation": psychological benefits of caregiving in relatives of young people with muscular dystrophy. J Neurol 2014; 261: 188-195.

8. Tomiak EM, Samson A, Miles SA, et al. Gender-specific differences in the psychosocial adjustment of parents of a child with duchenne muscular dystrophy (DMD)-Two points of view for a shared experience. Qualitative Research Journal 2007; 7: 2-21.

9. Windle $\mathrm{G}$ and Bennett KM. Caring relationships: How to promote resilience in challenging times. In: Ungar M (eds) The social ecology of resilience. New York: Springer, 2012. pp. 219231.

10. Ruiz-Robledillo N, De Andrés-García S, Pérez-Blasco J, et al. Highly resilient coping entails better perceived health, high social support and low morning cortisol levels in parents of children with autism spectrum disorder. Res Dev Disabil 2014; 3: 35: 686-695.

11. Aburn G, Gott $M$ and Hoare $K$. What is resilience? An integrative review of the empirical literature. J Adv Nurs 2016; 72: 980-1000. 
Glover AS, Long M, Hendron J \& Taylor BJ (in press) Understanding carer resilience in Duchenne Muscular Dystrophy: a systematic narrative review.Chronic IIIness [advance access; accepted 11 June 2018]

12. Masten AS. Ordinary magic: Resilience processes in development. Am Psychol 2001; 56: 227-238.

13. Kumpfer KL. Factors and Processes Contributing to Resilience: The Resilience Framework. In: Glantz MD and Johnson J, L. (eds). Resilience and Development: Positive Life Adaptions. New York: Kluwer Academic/Plenum Publishers, 1999, pp. 179-224.

14. Connor KM and Davidson JR. Development of a new resilience scale: The Connor-Davidson resilience scale (CD-RISC). Depress Anxiety 2003; 18: 76-82.

15. Kay SA. Emotion Regulation and Resilience: Overlooked Connections. Ind Organ Psychol 2016; 9: 411-415.

16. Donnellan WJ, Bennett KM and Soulsby LK. Family close but friends closer: exploring social support and resilience in older spousal dementia carers. Aging \& Ment Health 2016; 0: 1-7.

17. Wagnild G and Young H. Development and psychometric. J Nurs Meas 1993; 1: 165-178.

18. Earvolino-Ramirez M. Resilience: A concept analysis. Nurs Forum 2007; 42: 73-82.

19. Hutcheon EJ and Lashewicz B. Are Individuals With Disabilities and Their Families "Resilient"? Deconstructing and Recasting a Well-Intended Concept. J Soc Work Disabil Rehabil 2015; 14: 41-60.

20. Dixon-Woods $M$, Agarwal $S$, Jones $D$, et al. Synthesising qualitative and quantitative evidence: a review of possible methods. J Health Serv Res Policy 2005; 10: 45-53.

21. Taylor BJ, Killick C and McGlade A. Understanding and using research in social work. London: Sage, 2015.

22. Killick C, Taylor BJ. Professional decision making on elder abuse: systematic narrative review. J Elder Abuse Negl 2009; 21: 211-238.

23. Moher D, Liberati A, Tetzlaff J, Altman DG. Preferred Reporting Items for Systematic Reviews and Meta-Analyses: The PRISMA Statement. PLoS Med 2009; 6: 1-6.

24. Bennett J, Lubben F, Hogarth S, Campbell B. Systematic reviews of research in science education: rigour or rigidity? Int J Sci Educ 2005; 27: 387-406.

25. Lynn S, Aartsma-Rus A, Bushby K, Furlong P, et al. Measuring clinical effectiveness of medicinal products for the treatment of Duchenne muscular dystrophy. Neuromuscul Disord 2015; 25: 96-105.

26. McGinn T, Taylor B, McColgan M, et al. Social work literature searching: Current issues with databases and online search engines. Res Soc Work Pract 2016; 26: 266-27.

27. Mays N, Pope C and Popay J. Systematically reviewing qualitative and quantitative evidence to inform management and policy-making in the health field. J Health Serv Res Policy 2005; 10: 6-20.

28. Green J and Murton F. Diagnosis of Duchenne muscular dystrophy: parents' experiences and satisfaction. Child Care Health Dev 1996; 22: 113-128. 
Glover AS, Long M, Hendron J \& Taylor BJ (in press) Understanding carer resilience in Duchenne Muscular Dystrophy: a systematic narrative review. Chronic IIIness [advance access; accepted 11 June 2018]

29. Fujino H, Saito T, Matsumura T, et al. How Physicians Support Mothers of Children with Duchenne Muscular Dystrophy. J Child Neurol 2015; 30: 1287-1294.

30. Landfeldt $E$, Lindgren $P$, Bell CF, et al. Quantifying the burden of caregiving in Duchenne muscular dystrophy. J Neurol 2016; 263: 906-915.

31. Mah JK, Thannhauser JE, Kolski $\mathrm{H}$, et al. Parental stress and quality of life in children with neuromuscular disease. Pediatr Neurol 2008; 39: 102-107.

32. Nereo NE, Fee RJ, Hinton VJ. Parental stress in mothers of boys with duchenne muscular dystrophy. J Pediatr Psychol 2003; 28: 473-484.

33. Reid DT and Renwick RM. Relating familial stress to the psychosocial adjustment of adolescents with Duchenne muscular dystrophy. Int J Rehabil Res 2001; 24: 83-93.

34. Yılmaz O, Yıldııım SA, Öksüz C, et al. Mothers' depression and health-related quality of life in neuromuscular diseases: Role of functional independence level of the children. Pediatr Int 2010; 52: 648-652.

35. Mah JK, Thannhauser JE, McNeil DA, et al. Being the lifeline: The parent experience of caring for a child with neuromuscular disease on home mechanical ventilation. Neuromuscul Disord 2008 12; 18: 983-988.

36. Nozoe KT, Polesel DN, Moreira GA, et al. Sleep quality of mother-caregivers of Duchenne muscular dystrophy patients. Sleep Breath 2016; 20: 129-134.

37. Thomas PT, Rajaram P, Nalini A. Psychosocial Challenges in Family Caregiving with Children Suffering from Duchenne Muscular Dystrophy. Health Soc Work 2014; 39: 144-152.

38. Peay HL, Hollin I and Bridges J. Prioritizing Parental Associated with Duchenne Muscular Dystrophy Using Best-Worst Scaling. J Genet Couns 2015; 25: 305-313.

39. Yamaguchi M and Suzuki M. Becoming a back-up carer: Parenting sons with Duchenne muscular dystrophy transitioning into adulthood. Neuromuscul Disord 2015; 25: 85-93.

40. Bothwell JE, Dooley JM, Gordon KE, et al. Duchenne muscular dystrophy--parental perceptions. Clin Pediatr (Phila) 2002; 41: 105-109.

41. Kenneson A and Bobo JK. The effect of caregiving on women in families with Duchenne/Becker muscular dystrophy. Health Soc Care Community 2010; 18: 520-528.

42. Gravelle AM. Caring for a child with a progressive illness during the complex chronic phase: parents' experience of facing adversity. J Adv Nurs 1997; 25: 738-745.

43. Webb C. Parents' perspectives on coping with Duchenne muscular dystrophy. Child Care Health Dev 2005; 31: 385-396.

44. Thompson RJ, Zeman JL, Fanurik D, et al. The role of parent stress and coping and family functioning in parent and child adjustment to Duchenne muscular dystrophy. J Clin Psychol 1992; 48: 11-19.

45. Peay HL, Meiser B and Kinnett K. Mothers' psychological adaptation to Duchenne/Becker muscular dystrophy. Eur J Hum Genet 2015; 1-5. 
Glover AS, Long M, Hendron J \& Taylor BJ (in press) Understanding carer resilience in Duchenne Muscular Dystrophy: a systematic narrative review.Chronic IIIness [advance access; accepted 11 June 2018]

46. Friborg $\mathrm{O}$, Barlaug $\mathrm{D}$, Martinussen $\mathrm{M}$, et al. Resilience in relation to personality and intelligence. Int J Methods Psychiatr Res 2005; 14: 29-42.

47. Chen JY and Clark MJ. Family function in families of children with Duchenne muscular dystrophy. Fam Community Health 2007; 30: 296-304.

48. McCubbin MA and McCubbin HI. Families coping with illness: the resiliency model of family stress, adjustment, and adaptation. In: Danielson CB, Hamel-Bissell B, Winstead-Fry P, (eds) Families, Health, \& IIIness: Perspectives on Coping and Intervention. St. Louis: Mosby, 1993, p. 21-63.

49. Lazarus R and Folkman S. Stress, appraisal and coping. New York: Springer; 1984

50. Chen J. Mediators affecting family function in families of children with Duchenne muscular dystrophy. Kaohsiung J Med Sci 2008; 24: 514-522.

51. Sinclair VG and Wallston KA. The development and psychometric evaluation of the Brief Resilient Coping Scale. Assessment 2004; 11: 94-101.

52. Chen JY and Clark MJ. Family resources and parental health in families of children with Duchenne muscular dystrophy. J Nurs Res 2010; 18: 239-248.

53. James CA, Hadley DW, Holtzman NA, et al. How does the mode of inheritance of a genetic condition influence families? A study of guilt, blame, stigma, and understanding of inheritance and reproductive risks in families with $\mathrm{X}$-linked and autosomal recessive diseases. Genet Med 2006; 8: 234-242.

54. de Moura MS, Wutski $\mathrm{H}$, Voos $\mathrm{M}$, et al. Is functional dependence of Duchenne muscular dystrophy patients determinant of the quality of life and burden of their caregivers? Neuromuscul Disord 2015; 25: 52-57.

55. Boyer F, Drame M, Morrone I, et al. Factors relating to carer burden for families of persons with muscular dystrophy. J Rehabil Med 2006; 38: 309-315.

56. Magliano L, Patalano M, Sagliocchi A, et al. Burden, professional support, and social network in families of children and young adults with muscular dystrophies. Muscle Nerve 2015; 52: 13-21.

57. Abi Daoud MS, Dooley JM and Gordon KE. Depression in parents of children with duchenne muscular dystrophy. Pediatr Neurol 2004; 31: 16-19.

58. Chen J, Chen S, Jong Y, et al. A comparison of the stress and coping strategies between the parents of children with Duchenne muscular dystrophy and children with a fever. J Pediatr Nurs 2002; 17: 369-379.

59. Gagliardi BA. The Family's Experience of Living With a Child with Duchenne Muscular Dystrophhy. Appl Nurs Res 1991; 4: 159-164.

60. Fitzpatrick $C$ and Barry C. Cultural differences in family communication about Duchenne muscular dystrophy. Dev Med Child Neurol 1990; 32: 967-973. 
Glover AS, Long M, Hendron J \& Taylor BJ (in press) Understanding carer resilience in Duchenne Muscular Dystrophy: a systematic narrative review.Chronic Illness [advance access; accepted 11 June 2018]

61. Erby LH, Rushton C and Geller G. "My Son Is Still Walking": Stages of Receptivity to Discussions of Advance Care Planning Among Parents of Sons With Duchenne Muscular Dystrophy. Semin Pediatr Neurol 2006; 13: 132-140.

62. Samson A, Tomiak E, Dimillo J, et al. The lived experience of hope among parents of a child with Duchenne muscular dystrophy: perceiving the human being beyond the illness. Chronic IIIn 2009; 5: 103-114.

63. Bray P, Bundy AC, Ryan MN, K, et al. Health status of boys with Duchenne muscular dystrophy: A parent's perspective. J Paediatr Child Health 2010; 47: 557-762.

64. Baiardini I, Minetti C, Bonifacino S, et al. Quality of life in Duchenne muscular dystrophy: the subjective impact on children and parents. J Child Neurol 2011; 26: 707-713.

65. Read J, Kinali M, Muntoni F, et al. Siblings of young people with Duchenne muscular dystrophy - A qualitative study of impact and coping. Eur J Paediatr Neurol 2011; 15: 21-28.

66. Read J, Kinali M, Muntoni F, et al. Psychosocial adjustment in siblings of young people with Duchenne muscular dystrophy. Eur J Paediatr Neurol 2010; 14: 340-348.

67. Plumridge $G$, Metcalfe $A$, Coad J, et al. Family communication about genetic risk information: particular issues for Duchenne muscular dystrophy. Am J Med Genet A 2010; 152: $1225-1232$.

68. Hodges $L$ and Dibb B. Social Comparison within Self-help Groups Views of Parents of Children with Duchenne Muscular Dystrophy. J Health Psychol 2010; 15: 483-492.

69. Magliano L, D’Angelo MG, Vita G el al. Psychological and practical difficulties among parents and healthy siblings of children with Duchenne vs. Becker muscular dystrophy: an Italian comparative study. Acta Myol 2014; 33: 136-143.

70. Richardson GE. The metatheory of resilience and resiliency. J Clin Psychol 2002; 58: 307321.

71. Jowsey T, Strazdins L and Yen L. Worry and time: the unseen costs of informal care. Chronic IIIn 2016; 12: 249-260.

72. Nightingale CL, Curbow BA, Wingard JR, et al. Burden, quality of life, and social support in caregivers of patients undergoing radiotherapy for head and neck cancer: A pilot study. Chronic IIIn 2016; 12: 236-245.

73. Wingham J, Frost J, Britten $\mathrm{N}$, et al. Needs of caregivers in heart failure management: A qualitative study. Chronic IIIn 2015; 11: 304-319. 
Glover AS, Long M, Hendron J \& Taylor BJ (in press) Understanding carer resilience in Duchenne Muscular Dystrophy: a systematic narrative review. Chronic IIIness [advance access; accepted 11 June 2018]

\section{Appendix 1: Search Strategy}

"emotional intelligence" OR "ei" OR "eq" OR "emotional quotient" OR hardiness OR resilien* OR coping OR cope* OR adapt* W/3 psychological OR behavi* change* OR adapt* W/3 behavi* OR adjust* W/3 behavi* OR emotional adjustment* OR "psychological resilience" OR emotion* W/3 control*

AND

carer* OR "caregiver burden" OR caregiver* OR care giver* care giv* OR caregiv* OR "care giv*" OR parent* OR father* OR mother* OR sibling* OR brother*.

AND

"duchenne muscular dystrophy" OR "becker muscular dystrophy" 
Glover AS, Long M, Hendron J \& Taylor BJ (in press) Understanding carer resilience in Duchenne Muscular Dystrophy: a systematic narrative review.Chronic Illness [advance access; accepted 11 June 2018]

\section{Appendix 2: Data Extraction of Included Studies}

$\mathrm{N}=($ number of family carers) unless otherwise specified $\mathrm{HCP}=$ (number of health care professionals)

* Resilience concept measured

**Use of the term resilience

\begin{tabular}{|c|c|c|c|}
\hline Study Details & Participants & Research Design & Theme \\
\hline $\begin{array}{l}\text { Baiardini et al. } \\
\text { (2011), } \\
\text { Italy. }^{(64)}\end{array}$ & $\mathrm{N}=27$ & Survey & $\begin{array}{l}\text { Strength of the } \\
\text { family unit }\end{array}$ \\
\hline $\begin{array}{l}\text { Bothwell (2002), } \\
\text { Canada. }{ }^{(40)}\end{array}$ & $\mathrm{N}=31$ & Survey & Future challenges \\
\hline $\begin{array}{l}\text { Boyer et al. (2006), } \\
\text { France. }{ }^{(55)}\end{array}$ & $\mathrm{N}=56$ & Survey & Coping abilities \\
\hline $\begin{array}{l}\text { Bray et al. (2010), } \\
\text { Australia. }\end{array}$ & $\mathrm{N}=34$ & Survey & Coping abilities \\
\hline $\begin{array}{l}\text { Chen }(2008)^{*} \text {, } \\
\text { Taiwan. }{ }^{(50)}\end{array}$ & $\mathrm{N}=80$ & Survey & Hardiness \\
\hline $\begin{array}{l}\text { Chen et al. (2002), } \\
\text { Taiwan. }{ }^{(58)}\end{array}$ & $\mathrm{N}=31, \mathrm{~N}=30$ (control parents) & Survey & Coping abilities \\
\hline $\begin{array}{l}\text { Chen et al.* (2007), } \\
\text { Taiwan. }{ }^{(47)}\end{array}$ & $\mathrm{N}=80$ & Survey & $\begin{array}{l}\text { Family } \\
\text { functioning }\end{array}$ \\
\hline $\begin{array}{l}\text { Chen and Clark* } \\
\text { (2010), Taiwan. (52) }\end{array}$ & $N=126$ & Survey & $\begin{array}{l}\text { Positive physical } \\
\text { outcomes of } \\
\text { resilience }\end{array}$ \\
\hline $\begin{array}{l}\text { Daoud et al. (2004) } \\
\text { Canada. }{ }^{(57)}\end{array}$ & $\mathrm{N}=42$ & Survey & Coping abilities \\
\hline $\begin{array}{l}\text { Erby et al. (2006), } \\
\text { USA. }{ }^{(61)}\end{array}$ & $\mathrm{N}=17$ & $\begin{array}{l}\text { Semi-structured } \\
\text { interview }\end{array}$ & Coping abilities \\
\hline
\end{tabular}


Glover AS, Long M, Hendron J \& Taylor BJ (in press) Understanding carer resilience in Duchenne Muscular Dystrophy: a systematic narrative review.Chronic Illness [advance access; accepted 11 June 2018]

\begin{tabular}{|c|c|c|c|}
\hline $\begin{array}{l}\text { Fitzpatrick and Barry } \\
\text { (1990), USA and } \\
\text { Ireland. }{ }^{(60)}\end{array}$ & $\mathrm{N}=34 \mathrm{I}($ Irish) $\mathrm{N}=23$ (American) & Survey & $\begin{array}{l}\text { The role of } \\
\text { support } \\
\text { mechanisms }\end{array}$ \\
\hline $\begin{array}{l}\text { Fujino et al. (2015), } \\
\text { Japan. }{ }^{(29)}\end{array}$ & $\mathrm{HCP}=263$ neurologists. & Survey & Past challenges \\
\hline $\begin{array}{l}\text { Gagliardi (1991), } \\
\text { USA. }{ }^{(59)}\end{array}$ & $N=6$ & $\begin{array}{l}\text { Naturalistic case } \\
\text { study }\end{array}$ & Coping abilities \\
\hline $\begin{array}{l}\text { Gravelle (1997), } \\
\text { Canada. (42) }\end{array}$ & $\mathrm{N}=11$ & $\begin{array}{l}\text { Semi-structured } \\
\text { interview }\end{array}$ & $\begin{array}{l}\text { Defining } \\
\text { adversity }\end{array}$ \\
\hline $\begin{array}{l}\text { Green and Murton } \\
\text { (1996), UK. }{ }^{(28)}\end{array}$ & $N=158$ & Survey & Past challenges \\
\hline $\begin{array}{l}\text { Hodges and Dibb } \\
(2010) \text {, UK. }{ }^{(68)}\end{array}$ & $\mathrm{N}=8$ & $\begin{array}{l}\text { Semi-structured } \\
\text { interview }\end{array}$ & $\begin{array}{l}\text { The role of } \\
\text { support } \\
\text { mechanisms }\end{array}$ \\
\hline $\begin{array}{l}\text { James et al. (2006), } \\
\text { USA. }{ }^{(53)}\end{array}$ & $\mathrm{N}=96$ & Survey & Coping abilities \\
\hline $\begin{array}{l}\text { Kenneson and } \\
\text { Bobo*(2010), USA. } \\
\text { (41) }\end{array}$ & $\mathrm{N}=1238$ & Survey & $\begin{array}{l}\text { The outcome of } \\
\text { resilience } \\
\text { The role of } \\
\text { support } \\
\text { mechanisms }\end{array}$ \\
\hline $\begin{array}{l}\text { Landfeldt et al. } \\
\text { (2016), Germany, } \\
\text { Italy, UK and USA. (30) }\end{array}$ & $N=770$ & Survey & $\begin{array}{l}\text { Present } \\
\text { challenges }\end{array}$ \\
\hline $\begin{array}{l}\text { Magliano et al. } \\
*(2014)^{(7)} \\
\text { Italy. }\end{array}$ & $\mathrm{N}=502$ & Survey & Resilience \\
\hline $\begin{array}{l}\text { Magliano et al. } \\
(2015){ }^{(69),} \\
\text { Italy. }\end{array}$ & $N=336$ & Survey & Coping abilities \\
\hline $\begin{array}{l}\text { Magliano et al. } \\
(2015)^{(56)} \\
\text { Italy }\end{array}$ & $\mathrm{N}=502$ & Survey & $\begin{array}{l}\text { The role of } \\
\text { support } \\
\text { mechanisms }\end{array}$ \\
\hline
\end{tabular}


Glover AS, Long M, Hendron J \& Taylor BJ (in press) Understanding carer resilience in Duchenne Muscular Dystrophy: a systematic narrative review.Chronic Illness [advance access; accepted 11 June 2018]

\begin{tabular}{|c|c|c|c|}
\hline $\begin{array}{l}\text { Mah et al. }(2008)^{(31)} \text {, } \\
\text { Canada. }\end{array}$ & $\mathrm{N}=109$ & Survey & $\begin{array}{l}\text { Present } \\
\text { challenges }\end{array}$ \\
\hline $\begin{array}{l}\text { Mah et al. }(2008 \mathrm{I})^{(35)} \\
\text { Canada }\end{array}$ & $\mathrm{N}=19$ ) & $\begin{array}{l}\text { Semi-structured } \\
\text { interview }\end{array}$ & $\begin{array}{l}\text { Present } \\
\text { challenges }\end{array}$ \\
\hline $\begin{array}{l}\text { Moura et al. (2015), } \\
\text { Brazil. (54) }\end{array}$ & $\mathrm{N}=31, \mathrm{~N}=35$ (DMD patients) & $\begin{array}{l}\text { Survey }+ \\
\text { Physical } \\
\text { assessment of } \\
\text { patient }\end{array}$ & Coping abilities \\
\hline $\begin{array}{l}\text { Nereo et al. (2003), } \\
\text { USA. }{ }^{(32)}\end{array}$ & $\begin{array}{l}\mathrm{N}=112, \mathrm{~N}=800 \text { (mothers of } \\
\text { healthy children), } \mathrm{N}=28 \\
\text { (children with } \mathrm{CP}), \mathrm{N}=46 \\
\text { (siblings of DMD patients) }\end{array}$ & Survey & $\begin{array}{l}\text { Present } \\
\text { challenges }\end{array}$ \\
\hline $\begin{array}{l}\text { Nozoe et al. (2015), } \\
\text { Brazil. (36) }\end{array}$ & $\mathrm{N}=32 \mathrm{~N}=32$ (control group) & Survey & $\begin{array}{l}\text { Present } \\
\text { challenges }\end{array}$ \\
\hline $\begin{array}{l}\text { Pangalila et al. } \\
\text { (2012), } \\
\text { Netherlands. }{ }^{(6)}\end{array}$ & $\mathrm{N}=80$ & Survey & Coping abilities \\
\hline $\begin{array}{l}\text { Peay et al. }(2015)^{(38)} \text {, } \\
\text { USA }\end{array}$ & $\mathrm{N}=119$ & Survey & Future challenges \\
\hline $\begin{array}{l}\text { Peay et al. (2015), } \\
\text { USA. }{ }^{*}(45)\end{array}$ & $\mathrm{N}=205$ & Survey & Resilience \\
\hline $\begin{array}{l}\text { Plumridge et al. } \\
\text { (2010), } \\
\text { UK. }{ }^{(67)}\end{array}$ & $\mathrm{N}=52 \mathrm{~N}=44$ (children) & $\begin{array}{l}\text { Semi-structured } \\
\text { interview }\end{array}$ & $\begin{array}{l}\text { The role of } \\
\text { support } \\
\text { mechanisms }\end{array}$ \\
\hline $\begin{array}{l}\text { Read et al. (2010), } \\
\text { UK. }{ }^{(66)}\end{array}$ & $\mathrm{N}=46$ & Survey & $\begin{array}{l}\text { Strength of the } \\
\text { family unit }\end{array}$ \\
\hline $\begin{array}{l}\text { Read et al. (2011), } \\
\text { UK. }{ }^{(65)}\end{array}$ & $\begin{array}{l}\mathrm{N}=35 \text { (siblings) } \mathrm{N}=29 \\
\text { (parents) }\end{array}$ & $\begin{array}{l}\text { Semi-structured } \\
\text { interview }\end{array}$ & $\begin{array}{l}\text { Strength of the } \\
\text { family unit }\end{array}$ \\
\hline
\end{tabular}


Glover AS, Long M, Hendron J \& Taylor BJ (in press) Understanding carer resilience in Duchenne Muscular Dystrophy: a systematic narrative review.Chronic Illness [advance access; accepted 11 June 2018]

\begin{tabular}{|c|c|c|c|}
\hline $\begin{array}{l}\text { Reid and Renwick } \\
\text { (2001), Canada. }{ }^{(33)}\end{array}$ & $\mathrm{N}=36 \mathrm{~N}=32$ (patients) & Survey & $\begin{array}{l}\text { Present } \\
\text { challenges }\end{array}$ \\
\hline $\begin{array}{l}\text { Samson et al. (2009), } \\
\text { Canada. }{ }^{(62)}\end{array}$ & $\mathrm{N}=11$ & $\begin{array}{l}\text { Semi-structured } \\
\text { interview }\end{array}$ & Coping abilities \\
\hline $\begin{array}{l}\text { Thomas et al. (2014), } \\
\text { India. (37) }\end{array}$ & $\mathrm{N}=60$ & Survey & Future challenges \\
\hline $\begin{array}{l}\text { Thompson et al. } \\
(1992)^{* *} \\
\text { USA }{ }^{(44)}\end{array}$ & $\mathrm{N}=35$ & Survey & Resilience \\
\hline $\begin{array}{l}\text { Tomiak et al. (2007), } \\
\text { Canada (8) }\end{array}$ & $\mathrm{N}=11$ & $\begin{array}{l}\text { Semi-structured } \\
\text { interview }\end{array}$ & $\begin{array}{l}\text { Strength of the } \\
\text { family unit } \\
\text { The role of } \\
\text { support } \\
\text { mechanisms }\end{array}$ \\
\hline $\begin{array}{l}\text { Webb (2005)**, } \\
\text { USA. }{ }^{(43)}\end{array}$ & $\mathrm{N}=23$ & $\begin{array}{l}\text { Semi-structured } \\
\text { interview }\end{array}$ & Resilience \\
\hline $\begin{array}{l}\text { Yamaguchi and } \\
\text { Suzuki (2015), Japan. } \\
\text { (39) }\end{array}$ & $\mathrm{N}=18$ & $\begin{array}{l}\text { Semi-structured } \\
\text { interview }\end{array}$ & Future challenges \\
\hline $\begin{array}{l}\text { Yilmaz et al. (2010), } \\
\text { Turkey. }{ }^{(34)}\end{array}$ & $\mathrm{N}=40$ & Survey & $\begin{array}{l}\text { Present } \\
\text { challenges }\end{array}$ \\
\hline
\end{tabular}


Glover AS, Long M, Hendron J \& Taylor BJ (in press) Understanding carer resilience in Duchenne Muscular Dystrophy: a systematic narrative review.Chronic Illness [advance access; accepted 11 June 2018]

\section{Removed Figures - Figure 1}

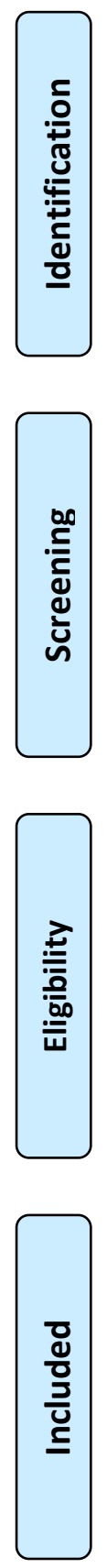

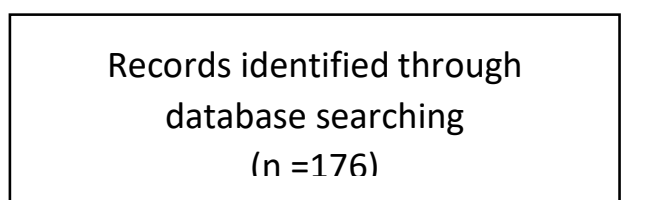

( $n=176)$
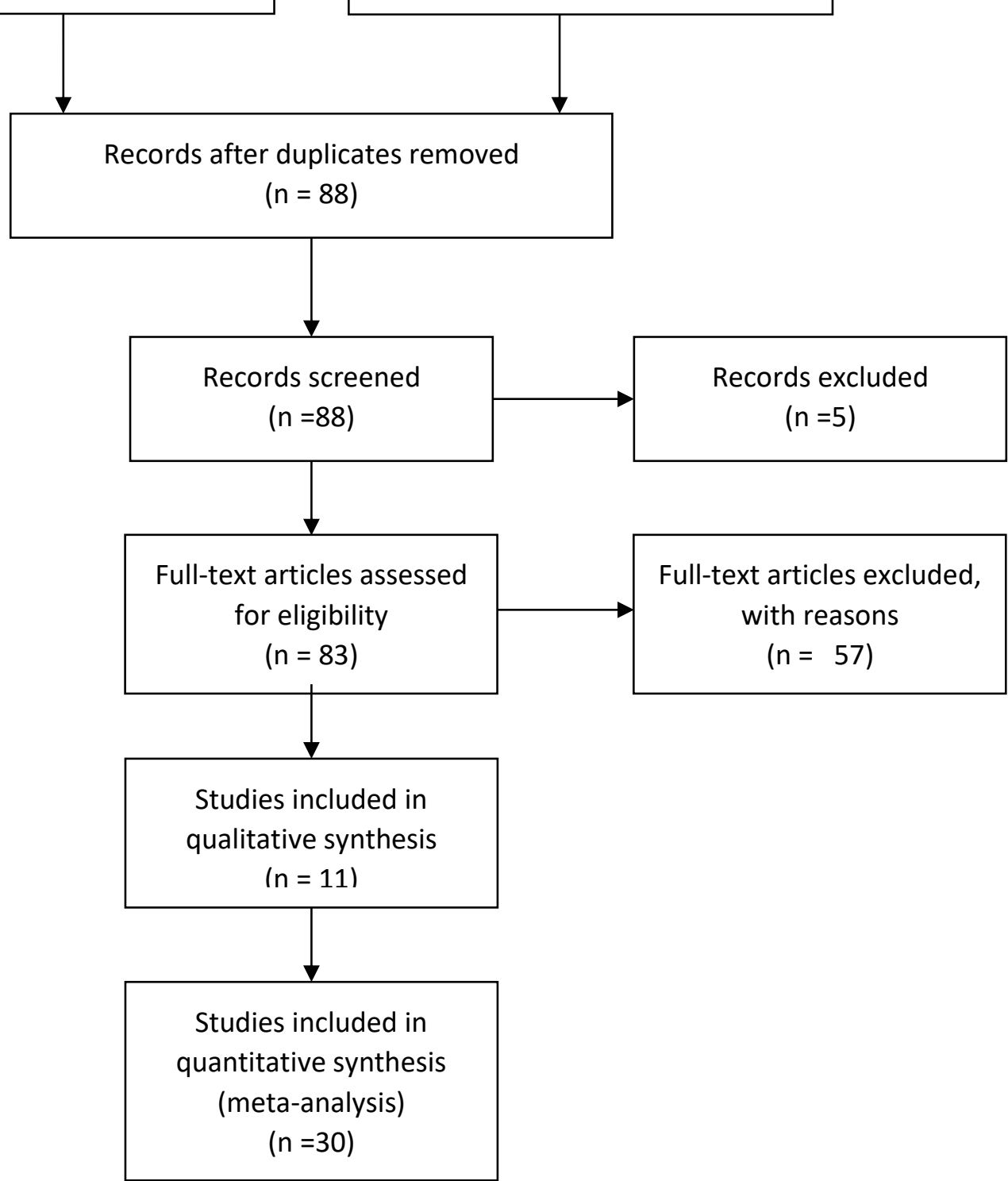

Additional records identified through other sources $(n=16)$ 
Glover AS, Long M, Hendron J \& Taylor BJ (in press) Understanding carer resilience in Duchenne Muscular Dystrophy: a systematic narrative review. Chronic IIIness [advance access; accepted 11 June 2018]

\section{Removed Tables}

Table 1: Inclusion and Exclusion Criteria

\begin{tabular}{|c|c|}
\hline Inclusion Criteria & Exclusion Criteria \\
\hline 1. Empirical research & 1. Publication pre 1990 \\
\hline $\begin{array}{l}\text { 2. Provides understanding of processes } \\
\text { and assets contributing to resilience }\end{array}$ & 2. Not in English \\
\hline 3. Emotionality of caring experience & $\begin{array}{l}\text { 3. Research focus lies outside the DMD caring } \\
\text { experience }\end{array}$ \\
\hline 4. Focus on Duchenne family carers & \\
\hline
\end{tabular}

